\title{
A new species of Proceratophrys Miranda-Ribeiro, 1920 (Anura, Odontophrynidae) of the $P$. bigibbosa species group from Southern Brazil
}

\author{
Diego José Santana ${ }^{1}$, Sarah Mângia ${ }^{1}$, Suélen da Silva Alves Saccol ${ }^{2}$, Tiago Gomes dos Santos ${ }^{3}$ \\ 1 Universidade Federal de Mato Grosso do Sul, Instituto de Biociências, 79070-900, Campo Grande, MS, Brazil \\ 2 Programa de Pós-Graduação em Biodiversidade Animal, Universidade Federal de Santa Maria, Departamento de Ecologia e Evolução, \\ 97105-900, Santa Maria, RS, Brazil \\ 3 Universidade Federal do Pampa, Campus São Gabriel, 97300-162, São Gabriel, RS, Brazil
}

http://zoobank.org/20976993-E3E7-40FF-B602-0D3E515F9DA0

Corresponding authors: Diego José Santana (jose.santana@ufms.br)

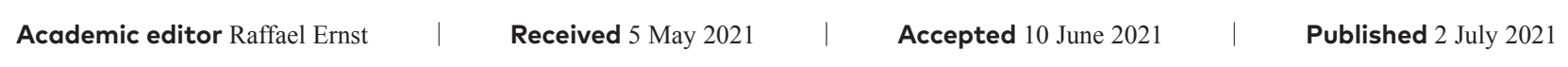

Citation: Santana DJ, Mângia S, da Silva Alves Saccol S, Gomes dos Santos T (2021) A new species of Proceratophrys Miranda-Ribeiro, 1920 (Anura, Odontophrynidae) of the P. bigibbosa species group from Southern Brazil. Vertebrate Zoology 71: 387-401. https://doi.org/10.3897/vz.71. e67894

\section{Abstract}

The monophyletic Proceratophrys bigibbosa species group has a stable taxonomic history. Despite the increasing number of Proceratophrys described in the last decades, the P. bigibbosa group, for a long time, has consisted of four species distributed in south of South America; except for P. palustris that occurs in southeastern Brazil. Herein, based on concordant evidence of morphology and mtDNA barcoding, we describe a new species of Proceratophrys for specimens assigned to the P. bigibbosa group collected in Tibagi municipality, Paraná state, Brazil. The new species is diagnosed by its small size, snout rounded in dorsal view, palpebral ridge with small and rounded tubercles, small postocular swellings, presence of a line of small and round tubercles on dorso-lateral region of body, and dorsal region covered by small, sparse, and rounded tubercles. We also highlight the potential occurrence of the new species in other areas along the Campos Gerais of Paraná, given the strong association of the species with this vegetational formation in South Brazil.

\section{Key words}

Morphology, mtDNA, Proceratophrys kaingang sp. nov., Southern Horned-Frogs

\section{Introduction}

The knowledge on the systematics and phylogenetic relationship among species in the genus Proceratophrys have rapidly increased in the last decades (Dias et al. 2013; Mângia et al. 2018, 2020; Magalhães et al. 2020). Nevertheless, the traditional morphological groups of Proceratophrys still lacks phylogenetic support. Despite that most of the groups recovered are paraphyletic, three clades were recurrently consistent with available phylogenetic analysis: a clade of restricted Caatinga species ( $P$. cristiceps, $P$. minuta, and $P$. redacta), the $P$. concavitympanum clade ( $P$. ararype, $P$. concavitympanum, $P$. moratoi, $P$. salvatori, and P. strussmannae) distributed in Amazonia, 
Cerrado, and Brejos de Altitude within the Caatinga, and the $P$. bigibbosa species group, composed of $P$. avelinoi, P. bigibbosa, P. brauni, and P. palustris (Teixeira-Jr et al. 2012; Mângia et al. 2018, 2020; Magalhães et al. 2020). Although the P. bigibbosa group has been recovered as monophyletic with high support, $P$. palustris still lacks DNA information and is placed in this group based on putative morphology basis.

The number of species of Proceratophrys has increased by $55 \%$ in the last two decades. However, the $P$. bigibbosa species group (revised 20 years ago by Kwet and Faivovich 2001) has a stable taxonomic history. Species within this group are mainly diagnosed by the presence of post ocular swellings and being distributed in southern of South America, except for P. palustris which is only known from its type locality in Poços de Caldas Plateau, south of Minas Gerais state, southeastern Brazil (Giaretta and Sazima 1993; Kwet and Faivovich 2001; Caldart et al. 2010).

During field expeditions in the Tibagi municipality, Paraná state, South Brazil, we collected specimens of Proceratophrys belonging to the $P$. bigibbosa species group, presenting one of the most northern distribution (except for $P$. palustris) that aroused questions about their taxonomy. We combined morphological and mtDNA barcoding evidence to elucidate its status and concluded that no available name could be applied to this population. Herein, we describe the population from Tibagi as a new taxon.

\section{Material and Methods}

\section{Sampling}

We conducted visual surveys at Tibagi municipality, in the Guartelá Canyon region from Campos Gerais of Paraná state, Brazil, in February 2016. All specimens were captured manually and killed using 5\% lidocaine, fixed in $10 \%$ formalin, and transferred to $70 \%$ ethanol for permanent storage (following Conselho Federal de Biologia-CFBio No 148/2012, 2012). Voucher specimens are housed in the Coleção de Anfíbios do Laboratório de Anfíbios e Répteis da Universidade Federal de Santa Maria (acronym ZUFSM), Santa Maria, Brazil, and Coleção Zoológica da Universidade Federal de Mato Grosso do Sul (acronym ZUFMS-AMP), Campo Grande, Brazil (Appendix I). We state here that appropriate protocols for the collection and handling of the individuals were followed for the present research according to Brazilian federal law. Collect permit was issue by ICMBio (SISBIO \#49876-1) and IAP (\#03.15).

\section{Morphology}

Specimens used in the description of the new species, as well as specimens examined for comparisons, are housed in 11 herpetological collections in Brazil (Appendix 1).
Terminology for morphological characters follows Kwet and Faivovich (2001), Prado and Pombal Jr. (2008), and Brandão et al. (2013). We follow Kwet and Faivovich (2001) for the ten morphometric variables: snout-vent length (SVL); head length, defined as the diagonal distance from the tip of the snout to the right angle of the jaw (HL); head width, defined as the distance between the angles of the jaw (HW); horizontal eye diameter (ED); eye-nostril distance (EN); nostril-snout distance (NS); internarial distance (IN); tibia length (TL); foot length (FL); inner metatarsal tubercle length (ML). All measurements were taken by DJS using a digital caliper (0.01 $\mathrm{mm}$ precision). We determined the sex of each individual by the presence of vocal slits in males and their absence in females.

\section{Phylogenetic inference and genetic distances}

We extracted genomic DNA from liver samples using the phenol-chloroform protocol (Sambrook and Russell 2001) and sequenced fragments of the $16 \mathrm{~S}$ ribosomal RNA mitochondrial gene from three individuals of the new species (genbank numbers provided in Appendix II). We used the $16 \mathrm{Sa} / 16 \mathrm{Sb}$ primer pair (Palumbi et al. 1991), following the polymerase chain reaction (PCR) conditions described by Costa et al. (2016). PCR reactions consisted of $1 \times$ buffer, dNTPs at $0.2 \mathrm{mM}$, each primer at $0.2 \mu \mathrm{M}, \mathrm{MgCl} 2$ at 2 $\mathrm{mM}, 1 \mathrm{U}$ Taq polymerase, and $2 \mu \mathrm{l}$ of template DNA, in a total reaction volume of $25 \mu \mathrm{l}$. We used the following PCR cycling program: $94^{\circ} \mathrm{C}$ for $2 \mathrm{~min}$, followed by 35 cycles of $94^{\circ} \mathrm{C}$ for $30 \mathrm{~s}, 59^{\circ} \mathrm{C}$ for $1 \mathrm{~min}$, and $72^{\circ} \mathrm{C}$ for $1 \mathrm{~min}$, and a final $5 \mathrm{~min}$ extension at $72^{\circ} \mathrm{C}$. We purified PCR products with Ethanol/Sodium Acetate and sequenced them on an ABI 3730XL DNA Analyzer (Applied Biosystems, Foster City, California). Resulting sequences were edited and aligned using Geneious v9.1.2 with the MUSCLE algorithm using default parameters (Edgar 2004). We aligned our $16 \mathrm{~S}$ sequences along with $16 \mathrm{~S}$ sequences of 28 species of Proceratophrys and with the outgroups Odontophrynus spp., Macrogenioglottus alipioi, Cycloramphus acangatan and Thoropa miliaris, which were available in GenBank (Appendix II). The final aligned dataset used in all analyses comprised 498 base pairs (bp) of 16S. We used the Bayesian Information Criterion in jModelTest (Darriba et al. 2012) to determine that $\mathrm{HKY}+\mathrm{I}+\mathrm{G}$ was the best model of nucleotide substitution for our 16S data set.

We performed a Bayesian phylogenetic analysis of 16S using BEAST v.2.6.3 (Bouckaert et al. 2019) for 20 million generations, sampling every 2,000 steps using a Yule Process tree prior. We checked for stationarity by visually inspecting trace plots and ensuring that all values for effective sample size were above 200 in Tracer v1.7.1 (Rambaut et al. 2018). The first $10 \%$ of sampled genealogies were discarded as burn-in, and the maximum clade credibility tree with median node ages was calculated with TreeAnnotator v.2.6.3 (Bouckaert et al. 2019). We also calculated sequence divergence (uncorrected p-distance, Appendix II) among species/individuals using MEGA v10.1.1 (Kumar et al. 2018). 


\section{Nomenclatural acts}

The electronic edition of this article conforms to the requirements of the amended International Code of Zoological Nomenclature, and hence the new names contained herein are available under that Code of this article. This published work and the nomenclatural acts it contains have been registered in ZooBank, the online registration system for the ICZN. The LSID (Life Science Identifier) for this publication is: LSIDurn:lsid:zoobank. org:pub:20976993-E3E7-40FF-B602-0D3E515F9DA0.

\section{Results}

\section{Proceratophrys kaingang sp. nov.}

http://zoobank.org/220976993-E3E7-40FF-B602-0D3E515F9DA0

Figs. 1-3

Holotype. ZUFSM 11127, adult female, collected at the Reserva Particular do Patrimônio Natural Rancho Sonho Meu (RPPN; Private Reserve of Natural Heritage), Tibagi municipality, in the Guartelá Canyon region from Campos Gerais of Paraná state, South Brazil $(-24,559588$, $-50,275243$ ), on 24 February 2016 by T. G. Santos, S. S. A. Saccol and A. A. B. Portela.

Paratypes. ZUFSM 11123, ZUFSM 11126, ZUFSM 11131, ZUFMSAMP14527-14530 (all adult males), ZUFSM 11132 and ZUFMSAMP14526 (adult females), collected with the holotype. ZUFSM 11079, ZUFSM 11080, ZUFSM 11081, and ZUFSM 11082 (adult males), collected at a private farmland $(-24.559588,-50.275243)$ on 22 February 2016, by the same collectors.

Diagnosis. Proceratophrys kaingang sp. nov. is diagnosed by the following combination of characters: (1) small size for P. bigibbosa group (SVL 22.97-27.10 mm in adult males, 33.46-39.36 $\mathrm{mm}$ in adult females); (2) snout rounded in ventral and dorsal views, obtuse in profile; (3) upper eyelid border with small, rounded tubercles of similar size, and fused; (4) small postocular swellings; (5) yellowish blotches on the venter (in life); (6) toe webbing poorly developed; (7) distinct tympanic membrane, bordered by rounded tubercles.

Comparison with other Species. Proceratophrys kaingang sp. nov. readily differs from $P$. appendiculata, $P$. belzebul, P. boiei, P. gladius, P. itamari, P. izecksohni, $P$. laticeps, P. mantiqueira, P. melanopogon, P. moehringi, P. paviotii, $P$. phyllostomus, $P$. pombali, $P$. renalis, $P$. rondonae, $P$. sanctaritae, $P$. subguttata, and $P$. tupinamba by the absence of a single unicuspidate palpebral appendage (a single and long unicuspidate palpebral appendage in all species, except in $P$. rondonae, which has a single and short multi-cuspidate palpebral appendage). In addition, $P$. kaingang sp. nov. can be distinguished from P. appen- diculata, P. belzebul, P. gladius, P. itamari, P. izecksohni, P. laticeps, P. mantiqueira, P. melanopogon, P. moehringi, P. phyllostomus, P. pombali, P. sanctaritae, P. subguttata, and $P$. tupinamba by lacking a rostral appendage (present in those species). Proceratophrys kaingang sp. nov. differs from P. ararype, P. bagnoi, P. branti, P. carranca, $P$. concavitympanum, $P$. cristiceps, $P$. cururu, $P$. dibernardoi, $P$. goyana, $P$. huntingtoni, $P$. minuta, $P$. moratoi, $P$. redacta, $P$. rotundipalpebra, $P$. salvatori, $P$. schirchi, $P$. strussmannae and $P$. vielliardi by the presence of post-ocular swellings (absent in these species).

Among the species from $P$. bigibbosa group, $P$. kaingang sp. nov. differs by (1) its smaller size (mostly in males): $22.97-27.10 \mathrm{~mm}$ in males, and $33.46-39.36 \mathrm{~mm}$ in females (P. brauni: $30.0-34.6 \mathrm{~mm}$ in males and 38.9 $39.8 \mathrm{~mm}$ in females; $P$. bigibbosa: $35.5-43.8 \mathrm{~mm}$ in males and 51.2-53.4 $\mathrm{mm}$ in females; Kwet and Faivovich, 2001; and P. palustris: $27.3-33.8 \mathrm{~mm}$ in males, Giaretta and Sazima, 1991), except from $P$. avelinoi that presents similar sizes (23.9-29.2 males and 30.2-36.5 in females); (2) snout rounded in dorsal view (P. brauni: pointed tip of the snout); (3) upper eyelid border with small, rounded tubercles of similar size, and fused ( $P$. avelinoi: small and triangular tubercles of varying sizes, and fused; $P$. bigibbosa: enlarged and pointed tubercles of varying sizes, not fused; P. brauni: long and triangular pointed tubercles of varying sizes, not fused); (4) small postocular swellings (P. bigibbosa, P. brauni and P. palustris: presence of two well-developed, bulbous, bony post-ocular swellings); (5) toe webbing poorly developed ( $P$. bigibbosa: well-developed toe webbing); (6) yellowish blotches on the venter ( $P$. avelinoi and $P$. brauni: venter with orange reddish blotches; $P$. bigibbosa: venter red irregularly spotted with black; $P$. palustris: venter darkgrey with small beige blotches); and (7) distinct tympanic membrane, bordered by rounded tubercles ( $P$. avelinoi: tympanic membrane indistinct, covered with minute homogeneous tubercles).

Description of the Holotype. Head wider than long (HL/ $\mathrm{HW}=0.70$ ), head length $32 \%$ of SVL, snout rounded in dorsal and ventral views, obtuse in profile; nares elliptical and prominent, canthal crests well marked, prominent, and covered by small tubercles; no preocular crests; eyes directed anterolaterally, eye diameter $38 \%$ of head length; eyelid with distinct, rounded tubercles, with the contact point between the ocular-dorsal ridge of warts and the external eyelid margin tubercles in a tubercle posterior to the post-ocular swellings, six warts on the border of the left eyelid and five on the right; sparse tubercles on the eyelid; distinct tympanum; vomerine teeth in two short rows between and below the choanae; frontoparietal crests well developed; region between frontoparietal crests shallow; interocular ridge of warts not organized in a row, with sparse small rounded tubercles; ocular-dorsal ridge of warts incomplete, and discontinued to the coccyx region. Dorsal surface, including flanks, arms and legs, with various warts of different sizes and shapes, a single row of tubercles in different sizes bordered with some sparse tubercles on the forearm; ventral surfaces, except 


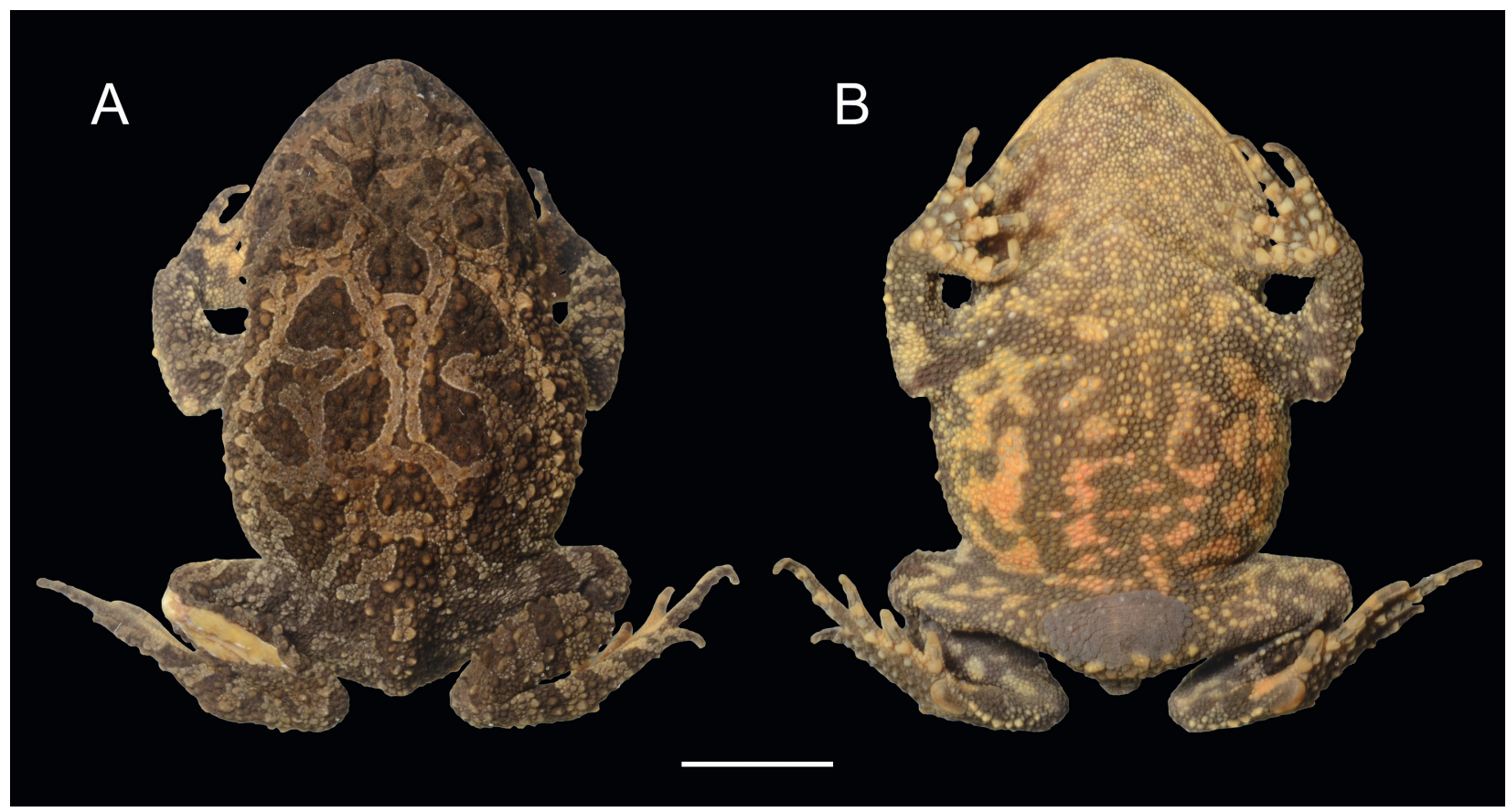

Figure 1. Holotype of Proceratophrys kaingang sp. nov. (ZUFSM11127). (A) Dorsal view of the body; and (B) ventral view of the body. Scale bar $=10 \mathrm{~mm}$.

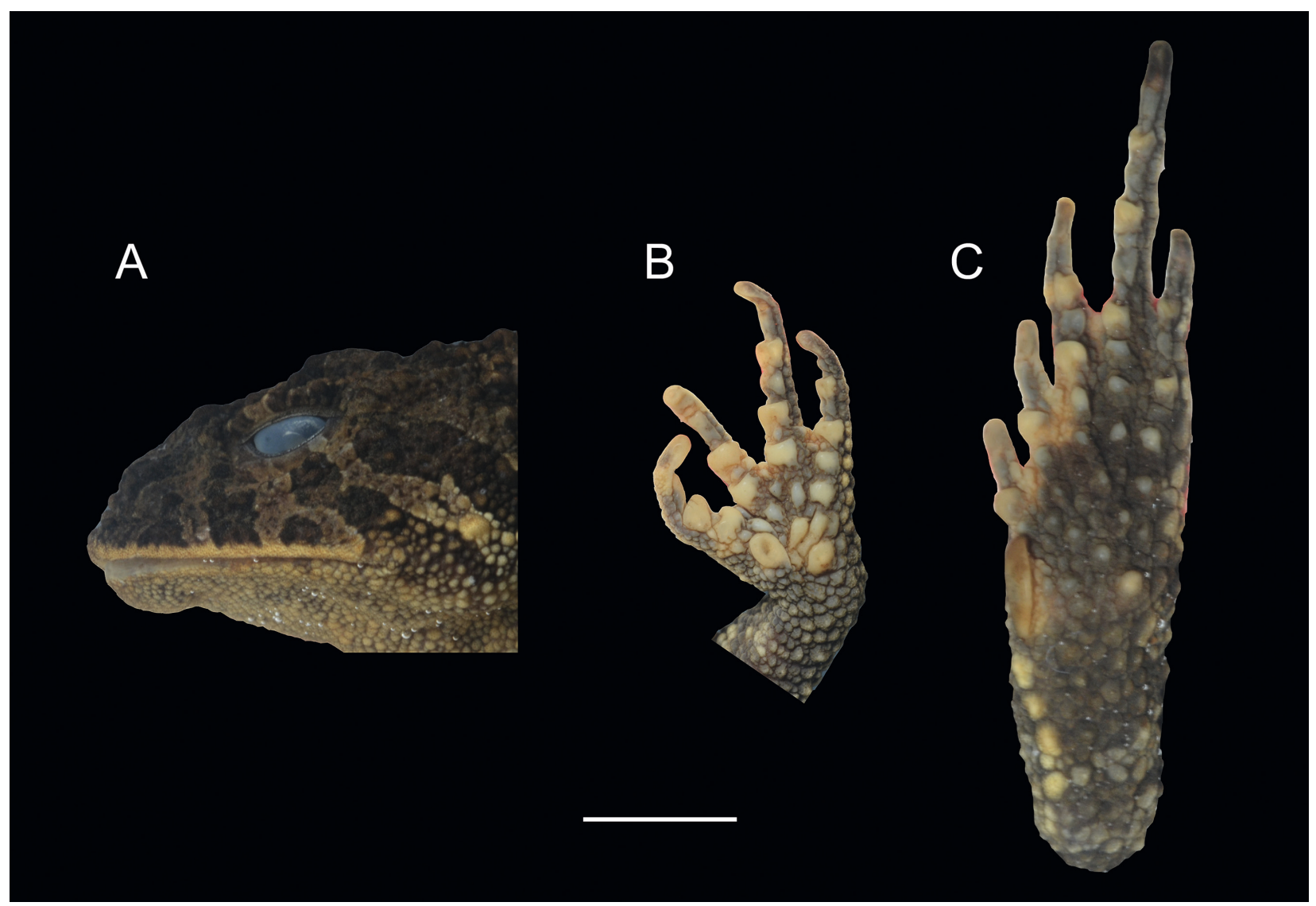

Figure 2. Holotype of Proceratophrys kaingang sp. nov. (ZUFSM11127). (A) Head lateral view; (B) ventral view of right hand; and (C) ventral view of right foot. Scale bar $=5 \mathrm{~mm}$

hands and feet and cloacal region, covered by numerous small, rounded, uniform warts. Finger lengths IV > II > I > III (Fig. 2b); interdigital webbing absent; inner metacarpal tubercle rounded; single outer metacarpal small, both internal and external are rounded; scarce small, rounded supernumerary tubercles; subarticular tubercles large, rounded, but grooved anteriorly and posteriorly. Toe lengths I $>$ II $>$ V $>$ III $>$ IV; inner metatarsal tubercle 


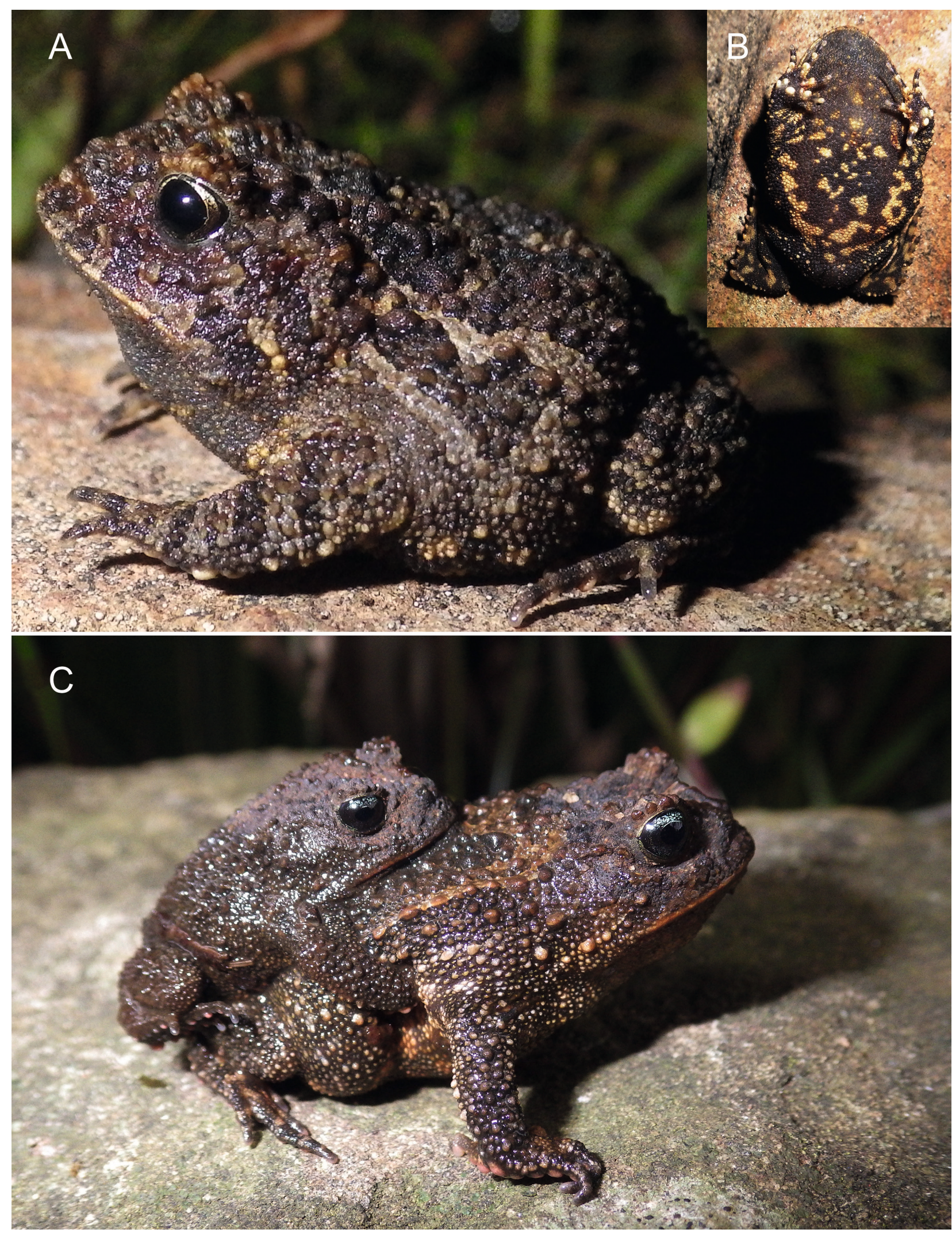

Figure 3. Live specimens of Proceratophrys kaingang sp. nov. from Parque Estadual do Guartelá (type locality), Tibagi municipality, Pará state, Brazil. (A) a live male (ZUFSM11127); (B) the ventral coloration in life of an adult male (ZUFSM11127); and (C) a couple in amplexus.

long, elliptical, poorly spatulated; outer metatarsal tubercle small, rounded; scarce small, rounded supernumerary tubercles; subarticular tubercles large, nearly rounded, grooved anteriorly and posteriorly.
Color Pattern in Life (Fig 3). Dorsal coloration overall in variable shades of brown, with regular patterns of dark brown blotches in the dorsum. Presence of longitudinal irregular stripes of light brown in dorsolateral region. Gu- 
Table 1. Morphometric measurements ( $\mathrm{mm}$ ) for the type series of Proceratophrys kaingang sp. nov. Measurement acronyms: snout-vent length (SVL); head length, defined as the diagonal distance from the tip of the snout to the right angle of the jaw (HL); head width, defined as the distance between the angles of the jaw (HW); horizontal eye diameter (ED); eye-nostril distance (EN); nostril-snout distance (NS); internarial distance (IN); tibia length (TL); foot length (FL); inner metatarsal tubercle length (ML).

\begin{tabular}{|l|l|l|l|l|l|l|l|}
\hline \multirow{2}{*}{ Measurement } & Holotype & \multicolumn{2}{l}{ Males } \\
& ZUFSM11127 & Average & SD & Range & \multicolumn{2}{l|}{ Females } \\
\cline { 3 - 8 } & 39.36 & 25.18 & 1.54 & $22.97-27.10$ & 35.87 & 3.10 & $33.46-39.36$ \\
\hline SVL & 12.40 & 8.58 & 0.95 & $7.31-10.25$ & 11.71 & 0.66 & $11.08-12.40$ \\
\hline HL & 17.77 & 11.84 & 0.81 & $10.15-12.86$ & 16.13 & 1.42 & $15.30-17.77$ \\
\hline HW & 3.85 & 3.19 & 0.38 & $2.42-3.95$ & 3.70 & 0.39 & $3.25-3.99$ \\
\hline ED & 3.90 & 2.85 & 0.41 & $2.24-3.64$ & 3.72 & 0.20 & $3.51-3.90$ \\
\hline EN & 3.28 & 2.51 & 0.22 & $2.09-2.76$ & 3.34 & 0.35 & $3.03-3.72$ \\
\hline NS & 2.63 & 1.94 & 0.20 & $1.61-2.35$ & 2.57 & 0.08 & $2.48-2.63$ \\
\hline IN & 13.99 & 9.12 & 0.65 & $8.24-10.09$ & 12.70 & 1.15 & $11.79-13.99$ \\
\hline TL & 22.56 & 14.45 & 0.96 & $12.88-16.45$ & 20.30 & 1.96 & $19.00-22.56$ \\
\hline FL & 2.67 & 1.71 & 0.14 & $1.51-1.99$ & 2.30 & 0.38 & $1.91-2.67$ \\
\hline ML & 0.70 & 0.72 & 0.05 & $0.65-0.80$ & 0.73 & 0.03 & $0.70-0.76$ \\
\hline HL/HW & 0.32 & 0.34 & 0.03 & $0.31-0.38$ & 0.33 & 0.01 & $0.32-0.33$ \\
\hline HL/SVL & & & & & & & SD \\
\hline
\end{tabular}

Table 2. Unconrrected sequence divergence (p-distance) among Proceratophrys species within P. bigibbosa species group.

\begin{tabular}{|l|l|l|l|l|l|l|l|l|l|l|l|}
\hline & & $\mathbf{1}$ & $\mathbf{2}$ & $\mathbf{3}$ & $\mathbf{4}$ & $\mathbf{5}$ & $\mathbf{6}$ & $\mathbf{7}$ & $\mathbf{8}$ & $\mathbf{9}$ & $\mathbf{1 0}$ \\
\hline 1 & FJ685692 P. bigibbosa & - & & & & & & & & & \\
\hline 2 & MG798659 P. bigibbosa & 0.008 & - & & & & & & & & \\
\hline 3 & MG798660 P. bigibbosa & 0.008 & 0.000 & - & & & & & & & \\
\hline 4 & DQ283039 P. avelinoi & 0.047 & 0.047 & 0.047 & - & & & & & & \\
\hline 5 & KP295643 P. avelinoi & 0.047 & 0.047 & 0.047 & 0.000 & - & & & & & \\
\hline 6 & FJ685691 P. avelinoi & 0.042 & 0.042 & 0.042 & 0.004 & 0.004 & - & & & & \\
\hline 7 & KU495472 P. brauni & 0.047 & 0.051 & 0.051 & 0.038 & 0.038 & 0.034 & - & & & \\
\hline 8 & ZUFSM 11080 P. kaingang sp. nov. & 0.056 & 0.056 & 0.056 & 0.045 & 0.045 & 0.040 & 0.021 & - & & \\
\hline 9 & ZUFSM 11127 P. kaingang sp. nov. & 0.056 & 0.056 & 0.056 & 0.045 & 0.045 & 0.040 & 0.021 & 0.000 & - & \\
\hline 10 & ZUFSM 11082 P. kaingang sp. nov. & 0.056 & 0.056 & 0.056 & 0.045 & 0.045 & 0.040 & 0.021 & 0.000 & 0.000 & - \\
\hline
\end{tabular}

lar region cream colored with mottling dark brown. Belly dark brown to black, irregularly spotted with yellow. Ventral surface of limbs dark brown to black, spotted with yellowish marks. Palm, fingers, soles of foot and toes are black, with two to three transverse dark-brown bars on fingers and toes.

Color Pattern in Preservative. Overall coloration about the same as in life. However, the color became faded, and the light tones became darker. The longitudinal irregular stripes are brown in dorsal-lateral region. Gular region color beige with mottling dark brown. Belly dark brown irregularly spotted with beige.

Variation. The main variation within this species relies on the sexual size dimorphism, with females (Fig. 4; 33.46-39.36 mm) bigger than males (Fig. 5; 22.97-27.10 $\mathrm{mm}$ ); in addition, males have a darker gular region (Fig. 5). Overall, the tubercles on the dorsum can vary in size, and some can be rounded to triangular. The variation of the dorsal coloration is more prominent in the dark brown blotches that border the dorsal row of tubercles. The ventral pattern varying slightly on shape and size of yellowish blotches (Fig. 4 and 5).
Phylogenetic Inferences and Mitochondrial DNA Divergences. Our $16 \mathrm{~S}$ tree (Fig. 5) confidently recovered $P$. kaingang sp. nov. nested within the $P$. bigibbosa species group, and as the sister taxon of P. brauni ( $\mathrm{pp}>0.95)$. All nodes for species in the $P$. bigibbosa species group are well supported ( $\mathrm{pp}>0.95$ ); however, some deeper nodes within Proceratophrys had low posterior probabilities, probably due to the single based gene tree. Average sequence divergence between the new species and its congeners within the $P$. bigibbosa species group ranges from $2.1 \%$ (P. brauni) to $5.6 \%$ (P. bigibbosa) (Appendix II).

Distribution and Natural History. Proceratophrys kaingang sp. nov. is known only from its type locality, the Guartelá Canyon region, Tibagi municipality, in the Campos Gerais of Paraná state, Brazil (Fig. 7). Grassland physiognomies (e.g., rocky vegetational refuge, hygrophilous steppe, and grassy-woody steppe) are predominant in this region (Fig. 8), consisting of relictual vegetation that include Mixed Ombrophilous Forest and Cerrado mosaics (Carmo et al. 2012; Souza et al. 2018). Calling males and a female were found in temporary puddles and slow running waters associated to flooded grasslands in the Private Reserve of Natural Heritage (RPPN Rancho 


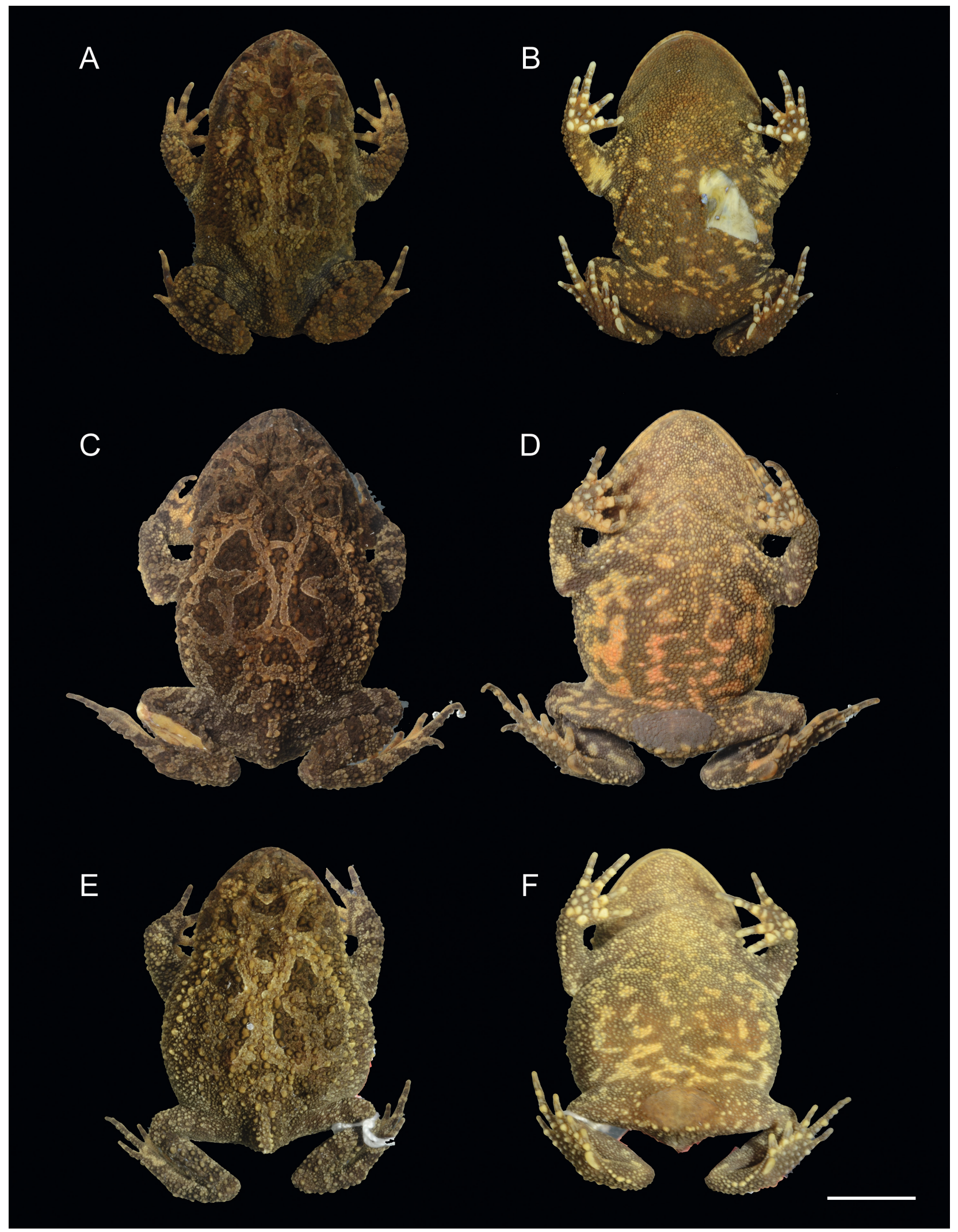

Figure 4. Dorsal and ventral color variation in preservative among female specimens from type series. (A) dorsal and (B) ventral views of ZUFSM11027 (holotype); (C) dorsal and (D) ventral views of ZUFSM11132; (E) dorsal and (F) ventral views of ZUFMSAMP14526. Scale bar $=10 \mathrm{~mm}$

Sonho $\mathrm{Meu}$ ) and in a wetland in agricultural landscape. Calling activity was recorded in both diurnal and nocturnal periods (from early afternoon until at least $\sim 11: 00 \mathrm{~h}$ $\mathrm{pm}$ ) during a historic event of heavy rains in the Paraná state. Males called from moist soil, exposed at the muddy edges of puddles as well as partially submerged in shallow flowing water, hidden among hygrophilous vegetation. Males of at least 12 other species were calling in the 


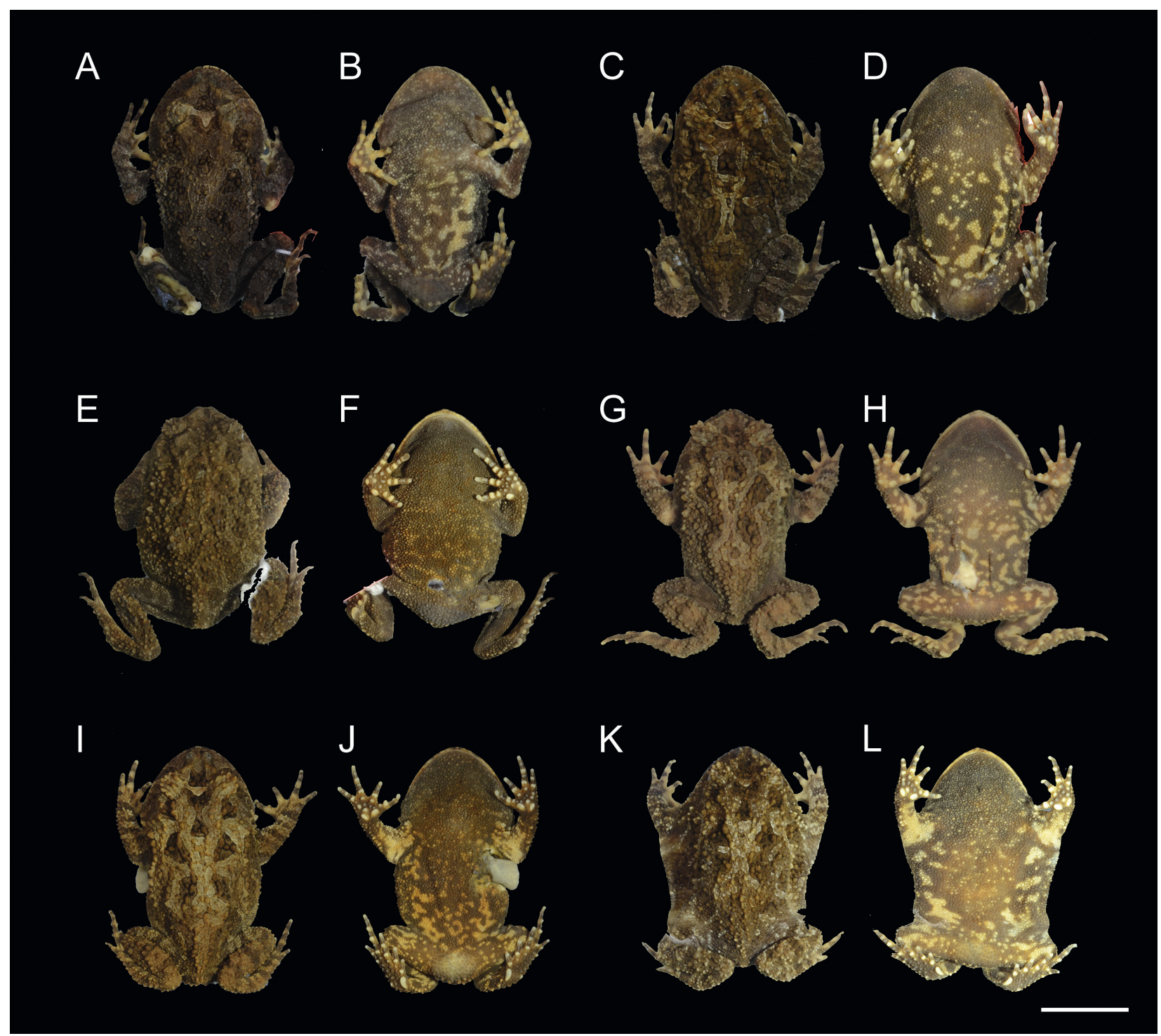

Figure 5. Dorsal and ventral color variation in preservative among male specimens from type series: (A) dorsal and (B) ventral views of ZUFSM11079; (C) dorsal and (D) ventral views ZUFSM11080; (E) dorsal and (F) ventral views of ZUFSM11131; (G) dorsal and $(\mathrm{H})$ ventral views of ZUFMS-AMP14528; (I) dorsal and (J) ventral views of ZUFMS-AMP14529; (K) dorsal and (L) ventral views of ZUFMS-AMP14530.

same breeding sites used by Proceratophrys kaingang sp. nov. (i.e., Aplastodiscus perviridis, Boana albpunctata, B. prasina, Dendropsophus minutus, Leptodactylus furnarius, L. fuscus, L. plaumanni, Melanoprhyniscus vilavelhensis, Physalaemus aff. gracilis, Scinax fuscovarius, S. rossaferesae, and $S$. squalirostris).

Etymology. The specific epithet kaingang is a noun in apposition referring to the Kaingang (or Caingangue) ethnic group, which inhabits the plateau regions of the states of Paraná, São Paulo, Rio Grande do Sul and Santa Catarina, Brazil. We suggest the following Portuguese vernacular names "sapo-de-chifre-dos-caingangue" or "sapo-de-chifre-do-guartelá".

\section{Discussion}

Proceratophrys kaingang sp. nov. is the fifth species of the $P$. bigibbosa species group. Similarly to other species within this group, the new species also occurs in open formations in ecotone areas with subtropical forests (Giaretta and Sazima 1993; Kwet and Faivovich 2001; Caldart et al. 2010). The geographical distribution of $P$. bigibbosa species group is similar to those reported for the genus Julianus that include a disjunct gap of $J$. pinima, i.e., a northern relictual distribution associated to rock outcrops of the Espinhaço Mountain Range of Minas Gerais state, and a southern distribution along the highland grasslands 


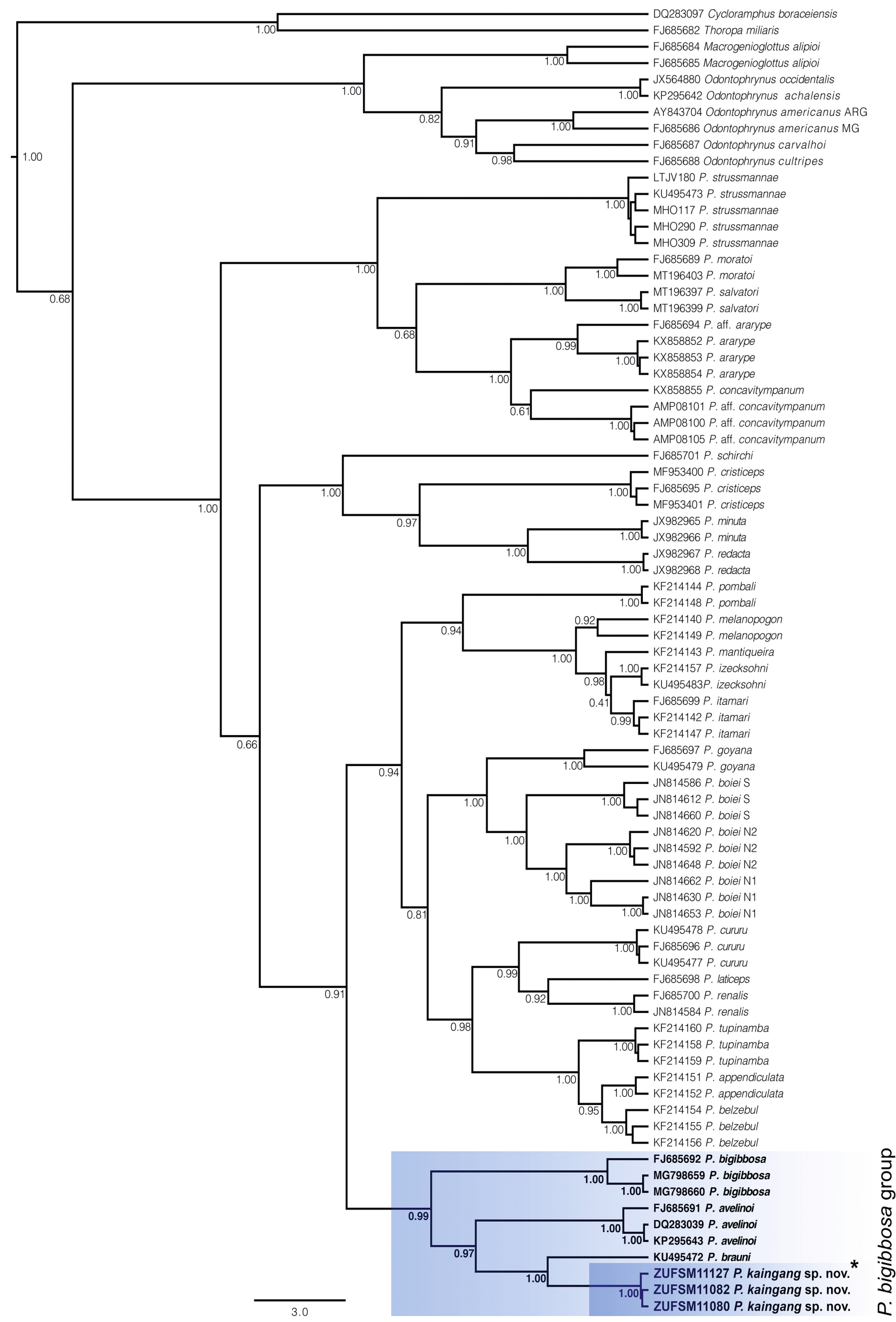

Figure 6. Gene tree based on phylogenetic analysis of the 16S mtDNA gene for the 28 species of the genus Proceratophrys. Scale indicates rate of base substitutions per site. 


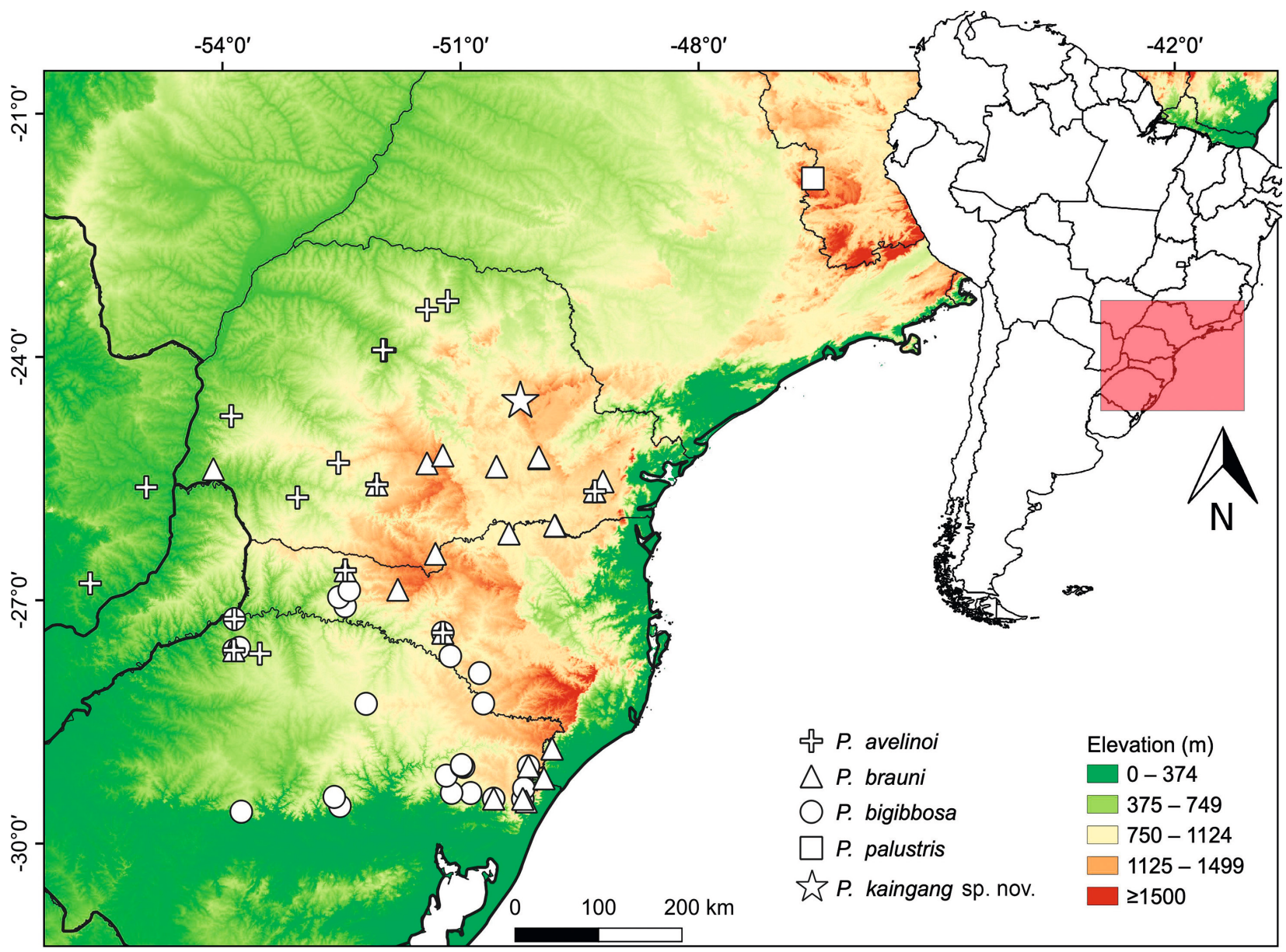

Figure 7. Geographic distribution of species from Proceratophrys bigibbosa species group in South America.

of Paraná, Santa Catarina and Rio Grande do Sul states (Baldo et al. 2019). In South Brazil, there is open formations along different vegetational ecotones. In the Tibagi area, the Guartelá Canyon region is a landscape of the Campos Gerais corresponding to the second plateau of Paraná state. The native landscape is characterized as a vegetational relict associated to southern grasslands (Campos Sulinos), Araucaria Forest (Floresta Ombrófila Mista), and Tropical savannah (Cerrado) (Carmo et al. 2012; da Maia and Goldenberg 2014; Souza et al. 2018). At least two other species occur in this region, Melanophryniscus vilavelhensis and Scinax rossaferesae, with distributions strongly associated to the region (Crivellari et al. 2014; Conte et al. 2016). These species are found in several areas along the Campos Gerais region of the second plateau of Paraná, we expect the occurrence of $P$. $k a$ ingang sp. nov. in different locations along this region. Historically, this open grasslands in Southern Brazil have been replaced by agricultural land (MMA 2000; Carmo et al. 2012), particularly soy bean and silviculture (mainly
Pinus and Eucalyptus). Our search for anuran fauna in ponds in the region, among crops and silviculture, but did not find any individual. However, we found the new species inside a conservation unit, where the population was in breeding activity.

Despite the stable taxonomic history of the P. bigibbosa species group in the last two decades, the description of $P$. kaingang sp. nov. and the rapid increase of species discovered in the genus highlights the need to study biogeographic and evolutionary patterns to better understand the species distribution. In addition, recent integrative approaches used in Proceratophrys taxonomy (Teixeira-Jr et al. 2012; Mângia et al. 2018, 2020; Magalhães et al. 2020;) should be applied to populations assigned to the $P$. bigibbosa group recently (Santos et al. 2009; Caldart et al. 2010; Carosini et al. 2010). Although P. kaingang sp. nov. is known only from its type locality, other populations belonging to the $P$. biggibosa group along the Campos Gerais of Paraná may reveal the real distribution of the new species and improved our knowledge to understand its conservational status. 

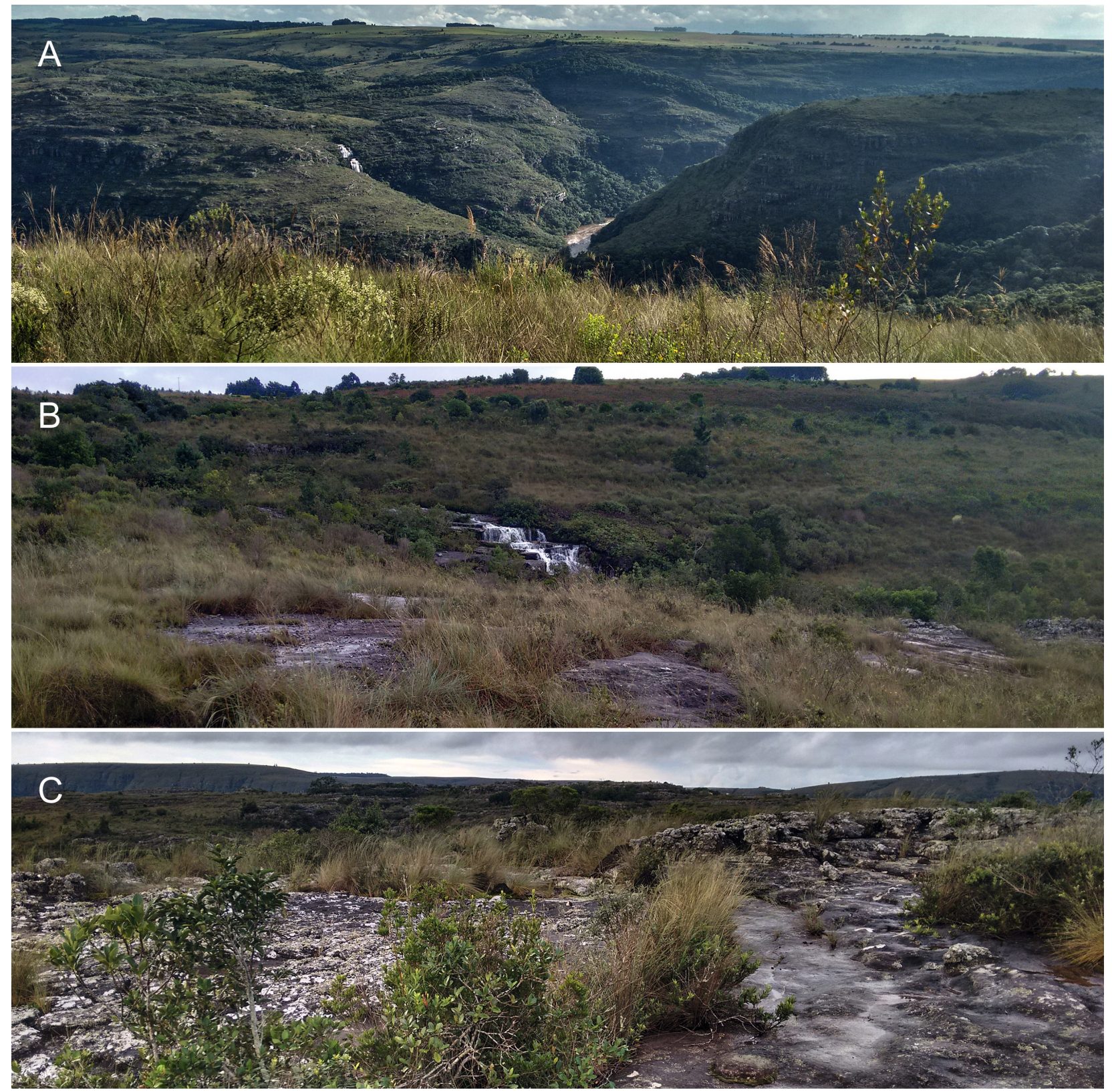

Figure 8. Habitat in which Proceratophrys kaingang sp. nov. was found. (A) General view of the Private Reserve of Natural Heritage (RPPN Rancho Sonho Meu), Tibagi municipality, in the Guartelá Canyon region from Campos Gerais of Paraná state, Brazil. (B) The predominant grassland physiognomies in the region, and (C) the rocky vegetational refuge, hygrophilous steppe and grassywoody steppe where the new species occurs.

\section{Acknowledgments}

DJS and TGS thank Conselho Nacional de Desenvolvimento Científico e Tecnológico for the research fellowships (CNPq 309420/2020-2 and CNPq 308687/2016-7, respectively). SSAS is grateful to CAPES (Coordenação de Aperfeiçoamento de Pessoal de Nível Superior) for doctoral fellowship. We also thank the Instituto Chico Mendes de Conservação da Biodiversidade (ICMBio) and Instituto Ambiental do Paraná (IAP) for issuing the collecting permit, as well as to the Neotropical Grassland Conservancy and the Programa de Pesquisa em Biodiversidade (PPBio) - Bioma Campos Sulinos (CNPq/MCTIC 457503/2012-2) for financial support. We thank all the landowners who granted access to the study sites, and to Sonia Z. Cechin (UFSM) for allowing us to examine specimens under her care.

\section{References}

Amaro RC, Pavan D, Rodrigues MT (2009) On the generic identity of Odontophrynus moratoi Jim \& Caramaschi, 1980 (Anura, Cycloramphidae). Zootaxa 2071: 61-68. https://doi.org/10.11646/zootaxa.2071.1.5

Amaro RC, Rodrigues MT, Yonenaga-Yassuda Y, Carnaval AC (2012) Demographic processes in the montane Atlantic rainforest: Molecular and cytogenetic evidence from the endemic frog Proceratophrys boiei. Molecular Phylogenetics and Evolution 62: 880-888. https:// doi.org/10.1016/j.ympev.2011.11.004

Baldo D, Araujo-Vieira K, Cardozo D, Borteiro C, Leal F, Pereyra MO, Kolenc F, Lyra ML, Garcia PCA, Haddad CFB, Faivovich J (2019) A review of the elusive bicolored iris Snouted Treefrogs (Anura: 
Hylidae: Scinax uruguayus group). Plos One 14(9): e0222131. https://doi.org/10.1371/journal.pone.0222131

Bouckaert R, Vaughan TG, Barido-Sottani J, Duchêne S, Fourment M, Gavryushkina A, Heled J, Jones G, Kühnert D, De Maio N (2019) BEAST 2.5: An advanced software platform for Bayesian evolutionary analysis. PLoS Computational Biology 15: e1006650. https:// doi.org/10.1371/journal.pcbi.1006650

Brandão RA, Caramaschi U, Vaz-Silva W, Campos LA (2013) Three new species of Proceratophrys Miranda-Ribeiro 1920 from Brazilian Cerrado (Anura, Odontophrynidae). Zootaxa 3750: 321-347. https://doi.org/10.11646/zootaxa.3750.4.2

Caldart VM, Iop S, Santos TG, Cechin SZ (2010) Extension of the geographical distribution of two anuran species for Rio Grande do Sul State, Brazil, with comments on natural history. Biota Neotropica 10: 143-147. https://doi.org/10.1590/S1676-06032010000300015

Carmo MRB, Andrade ALP, Santos GASD, Assis MA (2012) Análise estrutural em relictos de Cerrado no Parque Estadual do Guartelá, município de Tibagi, estado do Paraná, Brasil. Ciência Florestal 22: 505-517. https://dx.doi.org/10.5902/198050986618

Carosini A, Torres J, Pérez P, Valdez L, Sancha N (2010) Amphibia, Anura, Cycloramphidae, Proceratophrys avelinoi Mercadal de Barrio and Barrio, 1993: distribution extension and distribution map. Check List 6: 332-333. https://doi.org/10.15560/6.2.332

Conte CE, Araujo-Vieira K, Crivellari LB, Berneck BVM (2016) A new species of Scinax Wagler (Anura: Hylidae) from Paraná, Southern Brazil. Zootaxa 4193: 245-265. https://doi.org/10.11646/zootaxa.4193.2.3

Costa HC, Santana DJ, Leal F, Koroiva R, Garcia PCA (2016) A New Species of Helicops (Serpentes: Dipsadidae: Hydropsini) from Southeastern Brazil. Herpetologica 72: 157-166. https://doi. org/10.1655/HERPETOLOGICA-D-15-00059

Crivellari LB, Leivas PT, Leite JCM, Gonçalves DS, Mello CM, Rossa-Feres DC, Conte CE (2014) Amphibians of grasslands in the state of Paraná, southern Brazil (Campos Sulinos). Herpetology Notes 7: 639-654.

Darriba D, Taboada GL, Doallo R, Posada D (2012) JModelTest 2: More models, new heuristics and parallel computing. Nature Methods 9: 772. https://doi.org/10.1038/nmeth.2109

Dias PHS (2018) The tadpole of Proceratophrys bigibbosa (Peters, 1872) (Anura: Odontophrynidae), with a description of its buccopharyngeal morphology and proposal of novel synapomorphies for the P. bigibbosa species group. Copeia 106(1): 86-93. https://doi. org/10.1643/CH-17-630

Dias PHS, Amaro RC, Carvalho-e-Silva AMPT, Rodrigues MT (2013) Two new species of Proceratophrys Miranda-Ribeiro, 1920 (Anura; Odontophrynidae) from the Atlantic Forest, with taxonomic remarks on the genus. Zootaxa 3682: 277-304. https://doi.org/10.11646/zootaxa.3682.2.5

Edgar RC (2004) MUSCLE: a multiple sequence alignment method with reduced time and space complexity. BMC Bioinformatics 5: 113. https://doi.org/10.1186/1471-2105-5-113

Faivovich J, Haddad CFB, Garcia PCA, Frost DR, Campbell JA, Wheeler WC (2005) Systematic review of the frog family Hylidae, with special reference to Hylinae: phylogenetic analysis and taxonomic revision. Bulletin of the American Museum of Natural History 294: 1-240. https://dx.doi.org/10.5531/sd.sp.12

Faivovich J, Nicoli L, Blotto BL, Pereyra MO, Baldo D, Barrionuevo JS, Fabrezi M, Wild ER, Haddad CFB (2014) Big, Bad, and Beautiful: Phylogenetic Relationships of the Horned Frogs (Anura: Cer- atophryidae). South American Journal of Herpetology 9: 207-227. https://doi.org/10.2994/SAJH-D-14-00032.1

Frost DR, Grant T, Faivovich J, Bain RH, Haas A, Haddad CFB, de Sá RO, Channing A, Wilkinson M, Donnellan SC, Raxworthy CJ, Campbell JA, Blotto BL, Moler P, Drewes RC, Nussbaum RA, Lynch JD, Green DM, Wheeler WC (2006) The Amphibian Tree of Life. Bulletin of the American Museum of Natural History 297: 1-291. https://dx.doi.org/10.5531/sd.sp.13

Giaretta AA, Sazima I (1993) Nova espécie de Proceratophrys Mir. Rib. do Sul de Minas Gerais, Brasil (Amphibia, Anura, Leptodactylidae). Revista Brasileira de Biologia 53: 13-19.

Kumar S, Stecher G, Li M, Knyaz C, Tamura K (2018) MEGA X: Molecular evolutionary genetics analysis across computing platforms. Molecular Biology and Evolution 35: 1547-1549. https://doi. org/10.1093/molbev/msy096

Kwet A, Faivovich J (2001) Proceratophrys bigibbosa species group (Anura: Leptodactylidae), with description of a new species. Copeia 2001: 203-215. https://doi.org/10.1643/0045-8511(2001)001[0203: PBSGAL]2.0.CO;2

Lyra ML, Haddad CFB, Azeredo-Espin AML (2017) Meeting the challenge of DNA barcoding Neotropical amphibians: polymerase chain reaction optimization and new COI primers. Molecular Ecology Resources 17: 966-980. https://doi.org/10.1111/1755-0998.12648

Magalhães FM, Brandão RA, Garda AA, Mângia S (2020) Revisiting the generic position and acoustic diagnosis of Odontophrynus salvatori (Anura: Odontophrynidae). Herpetological Journal 30: 189196. https://doi.org/10.33256/hj30.4.189196

Maia FR, Goldenberg R (2014) Melastomataceae from the "Parque Estadual do Guartelá”, Tibagi, Paraná, Brazil: species list and field guide. Check List 10: 1316-1323. https://doi.org/10.15560/10.6.1316

Mângia S, Koroiva R, Nunes PMS, Roberto IJ, Ávila RW, Sant'Anna AC, Santana DJ, Garda AA (2018) A New Species of Proceratophrys (Amphibia: Anura: Odontophrynidae) from the Araripe Plateau, Ceará State, Northeastern Brazil. Herpetologica 74: 255-268. https://doi.org/10.1655/Herpetologica-D-16-00084.1

Mângia S, Oliveira EF, Santana DJ, Koroiva R, Paiva F, Garda AA (2020) Revising the taxonomy of Proceratophrys Miranda-Ribeiro, 1920 (Anura: Odontophrynidae) from the Brazilian semiarid Caatinga: Morphology, calls and molecules support a single widespread species. Journal of Zoological Systematics and Evolutionary Research 58: 1151-1172. https://doi.org/10.1111/jzs. 12365

MMA (2000) Avaliação e ações prioritárias para a conservação da biodiversidade da Mata Atlântica e Campos Sulinos. Secretaria de Biodiversidade e Florestas (SBF), Ministério do Meio Ambiente (MMA). Brasilia, 40 pp.

Murphy RW, Crawford AJ, Bauer AM, Che J, Donnellan SC, Fritz U, Haddad CFB, Nagy ZT, Poyarkov NA, Vences M, Wang WZ, Zhang YP (2013) Cold Code: the global initiative to DNA barcode amphibians and nonavian reptiles. Molecular Ecology Resources 13: 161-167. https://doi.org/10.1111/1755-0998.12050

Palumbi S, Martin RA, Romano S, McMillan WO, Stice L, Grabowski G (1991) The simple fool's Guide to PCR, Version 2. University of Hawaii Zoology Department, Honululu. 15 pp.

Prado GM, Pombal Jr JP (2008) Espécies de Proceratophrys Miranda-Ribeiro, 1920 com apêndices palpebrais (Anura; Cycloramphidae). Arquivos de Zoologia 39: 1-85. https://doi.org/10.11606/ issn.2176-7793.v39i1p1-85

Rambaut A, Drummond AJ, Xie D, Baele G, Suchard MA (2018) Posterior summarization in Bayesian phylogenetics using Tracer 1.7. Systematic Biology 67: 901-904. https://doi.org/10.1093/sysbio/syy032 
Sambrook J, Fritsch EF, Maniatis T (1989) Cold Spring Harbor Laboratory Press, New York, 2000 pp.

Santos RR, Colombo P, Leonardi SB, Zank C, Schossler M, Vieira K, Grant T, Borges-Martins M, Verrastro L (2009) Amphibia, Anura, Cycloramphidae, Proceratophrys bigibbosa (Peters, 1872) and Proceratophrys brauni Kwet and Faivovich, 2001: distribution extension and new state record. Check List 5: 922-925. https://doi. org/10.15560/5.4.922

Souza T, Trevisan R, Silva SM (2018) Synopsis of Poaceae in the grassland formations of the Parque Estadual do Guartelá, Paraná State, Brazil. Hoehnea 45: 202-224. https://doi.org/10.1590/2236-8906$36 / 2017$

\section{Appendix I}

\section{Additional Specimens Examined}

Acronyms: Coleção Herpetológica da Universidade Federal do Rio Grande do Norte (UFRN), Coleção Herpetológica da Universidade Federal de Pernambuco (CHUFPE), Museu de Zoologia da Universidade Federal da Bahia (MZUFBA), Coleção Zoológica da Universidade Federal de Mato Grosso (UFMT), Coleção Célio F. B. Haddad, Universidade Estadual Paulista (CFBH), Museu de Zoologia Prof. Adão José Cardoso, Universidade Estadual de Campinas (ZUEC), Museu de Zoologia da Universidade Estadual de Feira de Santana (MZFS), Coleção Herpetológica da Universidade Federal de Minas Gerais (CHUFMG), Museu de Ciências Naturais, Pontifícia Universidade Católica de Minas Gerais (MCNAM), Museu Nacional do Rio de Janeiro, Universidade Federal do Rio de Janeiro (MNRJ), and Coleção de Herpetologia da Universidade Regional do Cariri (URCAH).

Proceratophrys appendiculata. BRAZIL: RIO DE JANEIRO: Angra dos Reis: MNRJ 34016. Guapimirim: MNRJ 30983. Nova Friburgo: MNRJ 34017. Rio de Janeiro: MNRJ 31547.

Proceratophrys avelinoi. BRAZIL: RIO GRANDE DO SUL: Dois Irmãos das Missões: MCP 9772. Bom Progresso: MCP 13066.

Proceratophrys belzebul. BRAZIL: SÃO PAULO: Ubatuba: MNRJ 87144.

Proceratophrys bigibbosa. BRAZIL: RIO GRANDE DO SUL: São Francisco de Paula: MCP 2419, 3204.

Proceratophrys boiei. BRAZIL: ALAGOAS: Murici: MNRJ 9719-20, 9726-29, 9732. Passo de Camaragibe: MNRJ 9817, 9862, 9863, 9864. Quebrangulo: MNRJ 9972. RIO DE JANEIRO: Teresópolis: MNRJ 37328-32.

Proceratophrys branti. BRAZIL: TOCANTINS: Palmas: Taquarussu: UFMS AMP 5536-5538, 8118-8120; Novo Acordo: 8106.
Teixeira Jr M, Amaro RC, Recoder RS, Dal Vechio F, Rodrigues MT (2012) A new dwarf species of Proceratophrys Miranda-Ribeiro, 1920 (Anura, Cycloramphidae) from the highlands of Chapada Diamantina, Bahia, Brazil. Zootaxa 3551 25-42. https://doi. org/10.11646/zootaxa.3551.1.2

Proceratophrys brauni. BRAZIL: SANTA CATARINA: Timbé do Sul: MNRJ 25003-04. RIO GRANDE DO SUL: São Francisco de Paula: MCP 3686, 3769, 12940.

Proceratophrys carranca. BRAZIL: MINAS GERAIS: Buritizeiro: MNRJ 86440-42.

Proceratophrys cristiceps. BRAZIL: CEARÁ: Serra de Ibiapaba: UFPB 6117-26. Ubajara, Parque Nacional de Ubajara: AAGARDA 10672, 10695, 10698-99, 10703, 10707-09, 10782, 10796, 10907, 10909, 1091114, 10961, 10974, 10981, 10983. Várzea da Conceição: UFPB 9661, 9665, 9667. PIAUÍ: Floriano: UFPI 21416, 222, 236. Piripiri: UFPB 10340, 10342-46. RIO GRANDE DO NORTE: Serra Negra do Norte, Estação Ecológica do Seridó: AAGARDA 5447, 5528, 5583, 5689, 6061, 6790. João Câmara: AAGARDA 8913-15, 9806-11; URCA 422, 427, 483-85, 487-88, 493, 498, 501. Macaíba, Escola Agrícola de Jundiaí: AAGARDA 101314, 1019-20, 1753-71, 1773, 1776, 1778, 1786-91, 1935, 2495-96, 2583, 3757, 5447, 5528, 5554, 5583, 5689, 6061, 6790, 8866-71, 8913-15, 9806-11.

Proceratophrys concavitympanum. BRAZIL: MATO GROSSO: Aripuanã: MZUFV 9552, 9554-95556, UFMT 11697-11699; Colniza: UFMT 6808; Juína: UFMT 6996, 7825. RONDÔNIA: Espigão D’Oeste: CFBH 5135, 5136; Ministro Andreazza: CFBH 19815, CFBH 19818.

Proceratophrys cururu. BRAZIL: MINAS GERAIS: Santana do Riacho: MNRJ 17905.

Proceratophrys gladius. BRAZIL: SÃO PAULO: São José do Barreiro: MNRJ: 82577-79.

Proceratophrys goyana. BRAZIL: GOIÁS: Colinas do Sul: MNRJ 68292-95. Minaçu: MNRJ 17309-14. Rio São Miguel: MNRJ 47902. Veadeiros: MNRJ 47901, 47903- 04.

Proceratophrys itamari. BRAZIL: SÃO PAULO: Campos do Jordão: MNRJ 82580-84. 
Proceratophrys izecksohni. BRAZIL: RIO DE JANEIRO: Parati: MNRJ 88985-86.

Proceratophrys laticeps. BRAZIL: BAHIA: Ilhéus: MNRJ 4124-26, 13950-55. ESPÍRITO SANTO: Conceição da Barra: MNRJ 27946, 27949.

Proceratophrys mantiqueira. BRAZIL: MINAS GERAIS: Ervália: MNRJ 82573-76.

Proceratophrys melanopogon. BRAZIL: RIO DE JANEIRO: Resende: MNRJ 51654-705.

Proceratophrys minuta. BRAZIL: BAHIA: Miguel Calmon, Parque Estadual das Sete Passagens: MNRJ 75410-17.

Proceratophrys moehringi. BRAZIL: ESPÍRITO SANTO: Santa Teresa: MNRJ 46804.

Proceratophrys moratoi. BRAZIL: SÃO PAULO: Botucatu: MNRJ 60085.

Proceratophrys paviotii. BRAZIL: ESPÍRITO SANTO: Santa Teresa: MNRJ 84079-80; Aracruz: MNRJ 4018284.

Proceratophrys renalis. BRAZIL: ALAGOAS: Passo de Camaragibe: MNRJ 9817.
Proceratophrys rondonae. BRAZIL: RÔNDONIA: Bacia do Rio Branco: MNRJ 40906.

Proceratophrys sanctaritae. BRAZIL: BAHIA: Amargosa: MNRJ 62354-62357.

Proceratophrys schirchi. BRAZIL: BAHIA: Guaratinga: MNRJ 26459-60; Jussari: MNRJ 26456-58; Nilo Peçanha: MNRJ 26461. ESPÍRITO SANTO: Santa Teresa: MNRJ 18445-46, 56000-01.

Proceratophrys strussmannae. BRAZIL: MATO GROSSO: Vale de São Domingos: UFMT 1834, 1836, 7882, 7885, 8319,8320, 8377, 8380; Araputanga: UFMT 7879.

Proceratophrys subguttata. BRAZIL: SANTA CATARINA: Brusque: MNRJ 18282; São Bento do Sul: MNRJ 18281.

Proceratophrys tupinamba. BRAZIL: RIO DE JANEIRO: Angra dos Reis: MNRJ 25101-18, 38938.

Proceratophrys vielliardi. BRAZIL: GOIÁS: Caldas Novas: MNRJ 83314-15.

\section{Appendix II}

Genbank acession number and references of the sequences used in the present work.

\begin{tabular}{|l|l|l|}
\hline Species & Genbank Acession & Reference \\
\hline Cycloramphus boraceiensis & DQ283097 & Frost et al. (2006) \\
\hline Macrogenioglottus alipioi & FJ685684 & Amaro et al. (2009) \\
\hline Macrogenioglottus alipioi & FJ685685 & Amaro et al. (2009) \\
\hline Odontophrynus occidentalis & JX564880 & Murphy et al. (2013) \\
\hline Odontophrynus achalensis & KP295642 & Faivovich et al. (2014) \\
\hline Odontophrynus americanus MG & FJ685686 & Amaro et al. (2009) \\
\hline Odontophrynus carvalhoi & FJ685687 & Amaro et al. (2009) \\
\hline Odontophrynus cultripes & FJ685688 & Amaro et al. (2009) \\
\hline Odontpphrynus americanus ARG & AY843704 & Faivovich et al. (2005) \\
\hline Proceratophrys aff. ararype & FJ685694 & Amaro et al. (2009) \\
\hline Proceratophrys appendiculata & KF214151 & Dias et al. (2013) \\
\hline Proceratophrys appendiculata & KF214152 & Dias et al. (2013) \\
\hline Proceratophrys ararype & KX858852 & Mângia et al. (2018) \\
\hline Proceratophrys ararype & KX858853 & Mângia et al. (2018) \\
\hline Proceratophrys ararype & KX858854 & Mângia et al. (2018) \\
\hline Proceratophrys avelinoi & DQ283039 & Frost et al. (2006) \\
\hline Proceratophrys avelinoi & FJ685691 & Amaro et al. (2009) \\
\hline Proceratophrys avelinoi & KP295643 & Faivovich et al. (2014) \\
\hline Proceratophrys belzebul & KF214154 & Dias et al. (2013) \\
\hline Proceratophrys belzebul & KF214155 & Dias et al. (2013) \\
\hline Proceratophrys belzebul & KF214156 & Dias et al. (2013) \\
\hline & & \\
\hline
\end{tabular}




\begin{tabular}{|c|c|c|}
\hline Species & Genbank Acession & Reference \\
\hline Proceratophrys bigibbosa & FJ685692 & Amaro et al. (2009) \\
\hline Proceratophrys bigibbosa & MG798659 & Dias et al. (2018) \\
\hline Proceratophrys bigibbosa & MG798660 & Dias et al. (2018) \\
\hline Proceratophrys kaingang sp. nov. ZUFSM11080 & MW916088 & This study \\
\hline Proceratophrys kaingang sp. nov. ZUFSM11082 & MW916090 & This study \\
\hline Proceratophrys kaingang sp. nov. ZUFSM11127 & MW916089 & This study \\
\hline Proceratophrys boiei $\mathrm{N} 1$ & JN814630 & Amaro et al. (2012) \\
\hline Proceratophrys boiei $\mathrm{N} 1$ & JN814653 & Amaro et al. (2012) \\
\hline Proceratophrys boiei $\mathrm{N} 1$ & JN814662 & Amaro et al. (2012) \\
\hline Proceratophrys boiei $\mathrm{N} 2$ & JN814592 & Amaro et al. (2012) \\
\hline Proceratophrys boiei $\mathrm{N} 2$ & JN814620 & Amaro et al. (2012) \\
\hline Proceratophrys boiei $\mathrm{N} 2$ & JN814648 & Amaro et al. (2012) \\
\hline Proceratophrys boiei $\mathrm{S}$ & JN814586 & Amaro et al. (2012) \\
\hline Proceratophrys boiei $\mathrm{S}$ & JN814612 & Amaro et al. (2012) \\
\hline Proceratophrys boiei $\mathrm{S}$ & JN814660 & Amaro et al. (2012) \\
\hline Proceratophrys brauni & KU495472 & Lyra et al. (2017) \\
\hline Proceratophrys concavitympanum & KX858855 & Mângia et al. (2018) \\
\hline Proceratophrys cristiceps & FJ685695 & Amaro et al. (2009) \\
\hline Proceratophrys cristiceps & MF953400 & Mângia et al. (2018) \\
\hline Proceratophrys cristiceps & MF953401 & Mângia et al. (2018) \\
\hline Proceratophrys cururu & FJ685696 & Amaro et al. (2009) \\
\hline Proceratophrys cururu & KU495477 & Lyra et al. (2017) \\
\hline Proceratophrys cururu & KU495478 & Lyra et al. (2017) \\
\hline Proceratophrys goyana & FJ685697 & Amaro et al. (2009) \\
\hline Proceratophrys goyana & KU495479 & Lyra et al. (2017) \\
\hline Proceratophrys itamari & FJ685699 & Amaro et al. (2009) \\
\hline Proceratophrys itamari & KF214142 & Dias et al. (2013) \\
\hline Proceratophrys itamari & KF214147 & Dias et al. (2013) \\
\hline Proceratophrys izecksohni & KF214157 & Dias et al. (2013) \\
\hline Proceratophrys izecksohni & KU495483 & Lyra et al. (2017) \\
\hline Proceratophrys sp. & MW889930 & This study \\
\hline Proceratophrys sp. & MW889928 & This study \\
\hline Proceratophrys sp. & MW889929 & This study \\
\hline Proceratophrys laticeps & FJ685698 & Amaro et al. (2009) \\
\hline Proceratophrys mantiqueira & KF214143 & Dias et al. (2013) \\
\hline Proceratophrys melanopogon & KF214140 & Dias et al. (2013) \\
\hline Proceratophrys melanopogon & KF214149 & Dias et al. (2013) \\
\hline Proceratophrys minuta & JX982965 & Teixeira Jr et al. (2012) \\
\hline Proceratophrys minuta & JX982966 & Teixeira Jr et al. (2012) \\
\hline Proceratophrys moratoi & FJ685689 & Amaro et al. (2009) \\
\hline Proceratophrys moratoi & MT196403 & Magalhães et al. (2020) \\
\hline Proceratophrys pombali & KF214144 & Dias et al. (2013) \\
\hline Proceratophrys pombali & KF214148 & Dias et al. (2013) \\
\hline Proceratophrys redacta & JX982967 & Teixeira Jr et al. (2012) \\
\hline Proceratophrys redacta & JX982968 & Teixeira Jr et al. (2012) \\
\hline Proceratophrys renalis & FJ685700 & Amaro et al. (2009) \\
\hline Proceratophrys renalis & JN814584 & Amaro et al. (2012) \\
\hline Proceratophrys salvatori & MT196397 & Magalhães et al. (2020) \\
\hline Proceratophrys salvatori & MT196399 & Magalhães et al. (2020) \\
\hline Proceratophrys schirchi & FJ685701 & Amaro et al. (2009) \\
\hline Proceratophrys strussmannae & KU495473 & Lyra et al. (2017) \\
\hline Proceratophrys strussmannae & MZ264854 & This study \\
\hline Proceratophrys strussmannae & MZ264855 & This study \\
\hline Proceratophrys strussmannae & MZ264856 & This study \\
\hline Proceratophrys strussmannae & MZ264857 & This study \\
\hline Proceratophrys tupinamba & KF214158 & Dias et al. (2013) \\
\hline Proceratophrys tupinamba & KF214159 & Dias et al. (2013) \\
\hline Proceratophrys tupinamba & KF214160 & Dias et al. (2013) \\
\hline Thoropa miliaris & FJ685682 & Amaro et al. (2009) \\
\hline
\end{tabular}

